\title{
College Events
}

\section{Street Play Competition - August 23, 2017}

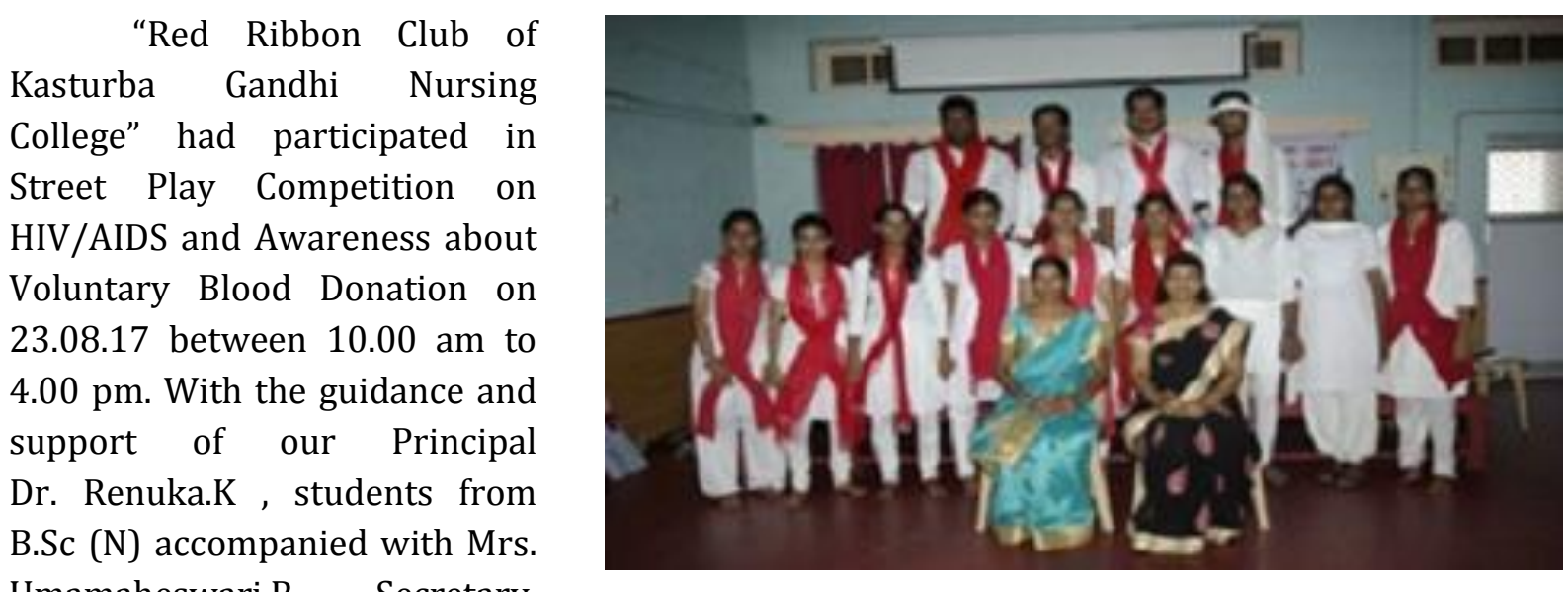

Umamaheswari.R, Secretary,

RRC,KGNC. participated in Street Play Competition on 23.08.17 between 10.00 am to 4.00 pm. It was organized by Pondicherry AIDS Control Society for Commemoration of International Youth Day. A team comprising of 13 B.Sc (N) students put up a Street play on the theme of HIV/AIDS Awareness. Totally 20 colleges participated actively \& their performances were judged Our Students won the Consolation Prize. Winners had been given cash award Rs.1000 with Certificates on the valediction. Evaluators appreciated the students for active participation.

\section{Career Enlightenment- Externship Program, - September 4, 2017}

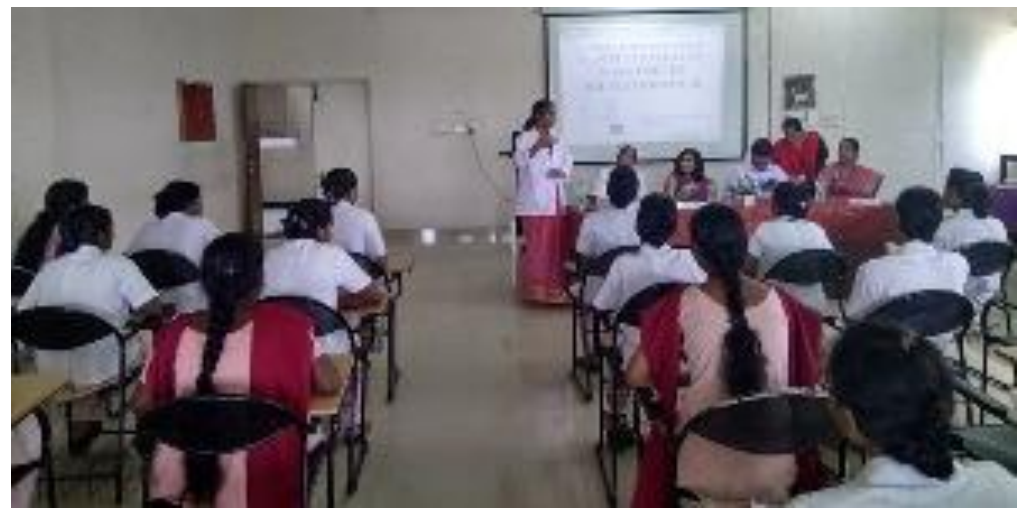

Placement cell, IQAC KGNC Unit organized Career Enlightenment- Externship Program for the final year B.Sc (N) (XI batch) students which commenced on 04.09.2017. The training Programme began with an inauguration at 9:30 am in I floor lecture hall, KGNC with College Anthem followed by lighting of kuthuvilakku by

HOD, Department of Physiology, was our special guest for the inauguration. Welcome address was delivered by Mrs. Rajeswari S, Placement Cell Officer, KGNC. Dr. Renuka K, Principal, KGNC, delivered the presidential address in which she highlighted the purpose, benefits and need of Career Enlightenment- Externship Program. Ms. Veronica A from final year B.Sc Nursing student shared her 4 years experiences in KGNC. She highlighted on the learning experiences provided by KGNC in terms of Theory, Practice and Research. She also expressed her gratitude to KGNC for providing all round development to the students. Prof. Sumathy. P, HOD, Department of Child Health Nursing felicitated the gathering. She emphasized the students to utilize the great 
opportunity given by our college and also she motivated the students to go for placement opportunities at various levels. The chief guest address was given by Dr. K. Jaiganesh , HOD, Department of Physiology. In his special message, he emphasized about how to overcome with workload by giving an example from basic physiology of break and accelerator system. He motivated the students for their professional development. Vote of thanks was given by Mrs. R. Elavarasi Asst. Prof, KGNC. The programme continued with the various sessions by eminent speakers and program concluded with the feedback obtained from the students.

\section{8th National Conference by Alumni Association of KGNC Sept-8, 2017}

KGNC in its journey towards excellence takes pride in hosting $8^{\text {th }}$ National conference, which is also coinciding with the conclusion of the year-long decennial celebration of the alumni. We take this opportunity to cherish the decennial alumni achievements, gratefully acknowledge the work and to reflect back on their hardwork, dedication and learning.

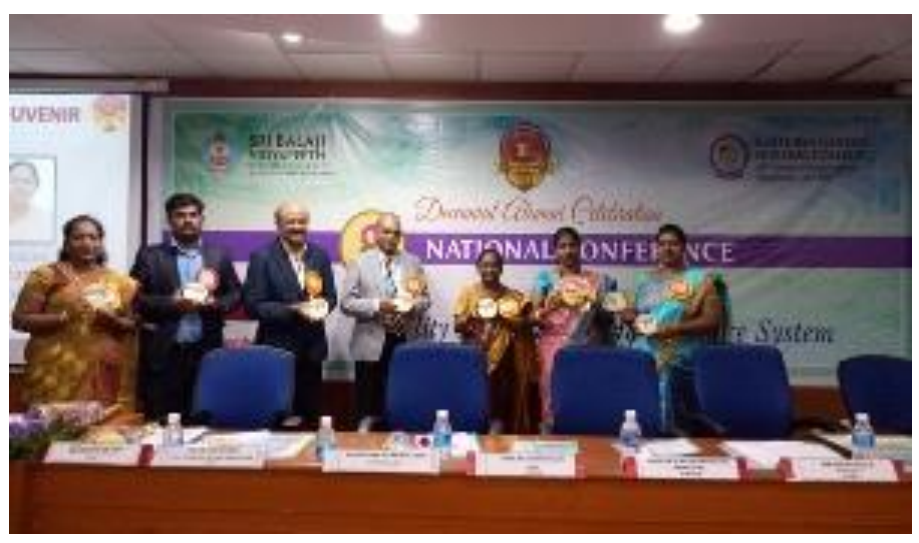

The pleasure pulses of the alumni always beats to keep up with excellence of an opportunity to reconnect and spread their alma mater by taking up the lead role in hosting the $8^{\text {th }}$ national conference on QUALITY PATHWAYS IN HEALTH CARE SYSTEM. The inaugural session commenced with a warm welcome accorded by the president of Alumni Association of KGNC Ms. RumaShanthini K. Our honorable Dean Prof. Ravishankar.M, SBV released the Stamp and rendered the Presidential Address .Followed by it Dr. Renuka K, Dean, Faculty Of Nursing Sciences, gave an Overview about the Conference. Dr. Vellore. A R Srinivasan, Registrar SBV inaugurated the Book Bank loan and felicitated the gathering. The Chief Guest, Prof. Dr. G. MuthamilSelvi Principal, VMCON released the souvenir and delivered the key note address.

The eminent speakers namely Prof. Dr. RenukaK, Principal, KGNC, Ms. Ruma Shanthini.K, Nursing Quality coordinator, Muhayel General Hospital, Saudi Arabia, Dr. G. Muthamilselvi, Principal, VMCON, Puducherry, Dr.Vijayalakshmi, Principal, Vignesh College of Nursing, Thiruvannamalai, Prof. Fabiola. M. Dhanaraj, Principal, Arulmigu Meenakshi College of Nursing, Kanchipuram, Mrs. Soya Sunny, Infection control Nurse, Paalana Institute of Medical sciences, Kerala, Mrs.Parvathy O G, Nurse Researcher, Bangalore and Mrs. Aruna Devi M, Asst. Prof, KGNC deliberated on various topics hospital informatics system at India and abroad, to promote leadership in quality health outcome and vision of Nursing 2025, and to excel all nurses as advanced nurse practitioners.

A large number of delegates from various parts of the state attended the conference with great interest and zeal. The day culminated with the national anthem in air 


\section{NEU, INFINITI -Mind Mapping Learning Model, September 9, 2017}

Nursing Education Unit \& Internal Quality Assurance Cell Jointly Organized a workshop on "INFINITI - Mind Mapping Learning Model", Which was conducted on 09.09.2017 between $9.30 \mathrm{am}-11.30 \mathrm{am}$, at I - Floor, MEU, MGMCRI. The Guest Speaker Dr. Renuka.K K, Principal, KGNC, deliberated on the topic "INFINITI - Mind Mapping Learning Model". The lecture was good eye opening session for the faculty to update their knowledge to lead the students. Mrs. Jayanthi, Assistant Professor, KGNC conducted the work session for the faculty members which was a lively and active session and the faculty members assured that they will be utilizing this "INFINITI - Mind Mapping Learning Model" for self and teaching students. There was a brief group discussion at the end of the session.

\section{Campus Interview, September 10, 2017}

Mahatma Gandhi Medical College Research Institute Conducted interview for our outgoing students on 9.10.17. Panel members of Staff Recruitment Mr. BalaMukundan, Personnel Manager, Dr.Swathi, DMS and Mrs.AmirAlikhanAsmath, Nursing Superintendent, conducted the interview. It comprised of two rounds written and oral test, 33 students attended the interview and all the students got selected.

\section{Children's Day - 14 ${ }^{\text {th }}$ November - 2017}

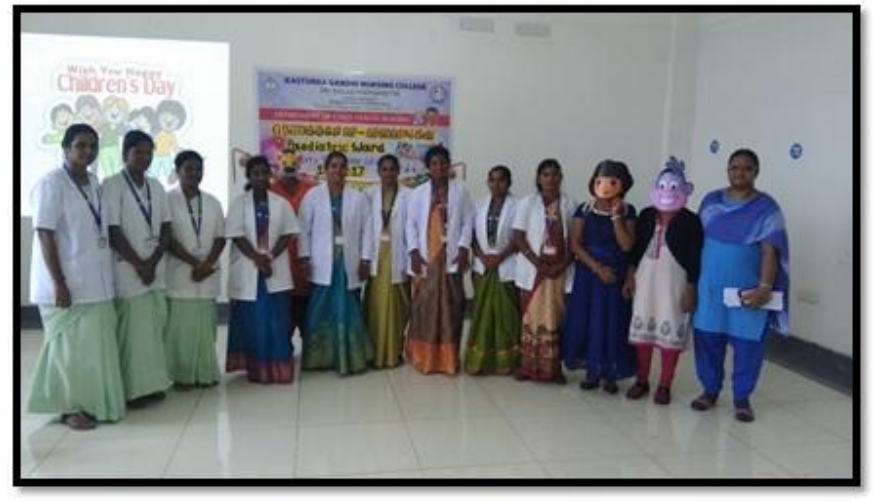

Children's day celebration was organized by the Department Of Child Health Nursing KGNC. IYear and II- year M.Sc Nursing Students, on 14.11.2017 between 9.30am and 11.00am staged a skit on "Ill effects of Junk Foods" at Paediatric Medical Ward, MGMCRI. To grab the attention of the audience.

The students transformed themselves as Dora, Boots and Swiper and conveyed the message in a simple, humorous and understandable way about the foods to be avoided, and their ill effects on Health and the foods to be taken alternatively instead of junk foods. Doctors, Department of Paediatrics, MGMCRI and faculty members of KGNC made their gracious presence. Around 30 parents with their children attended the programme, and they thoroughly enjoyed the programme. Thus, Children's Day celebration ended up with great joy and happiness. Feedback was collected from the parents and evaluated. $98 \%$ of the parents elicited that the programme was highly informative, interesting and excellent. 


\section{Newborn Week Celebration- 15 th to 21 ${ }^{\text {st }}$, November 15, 2017}

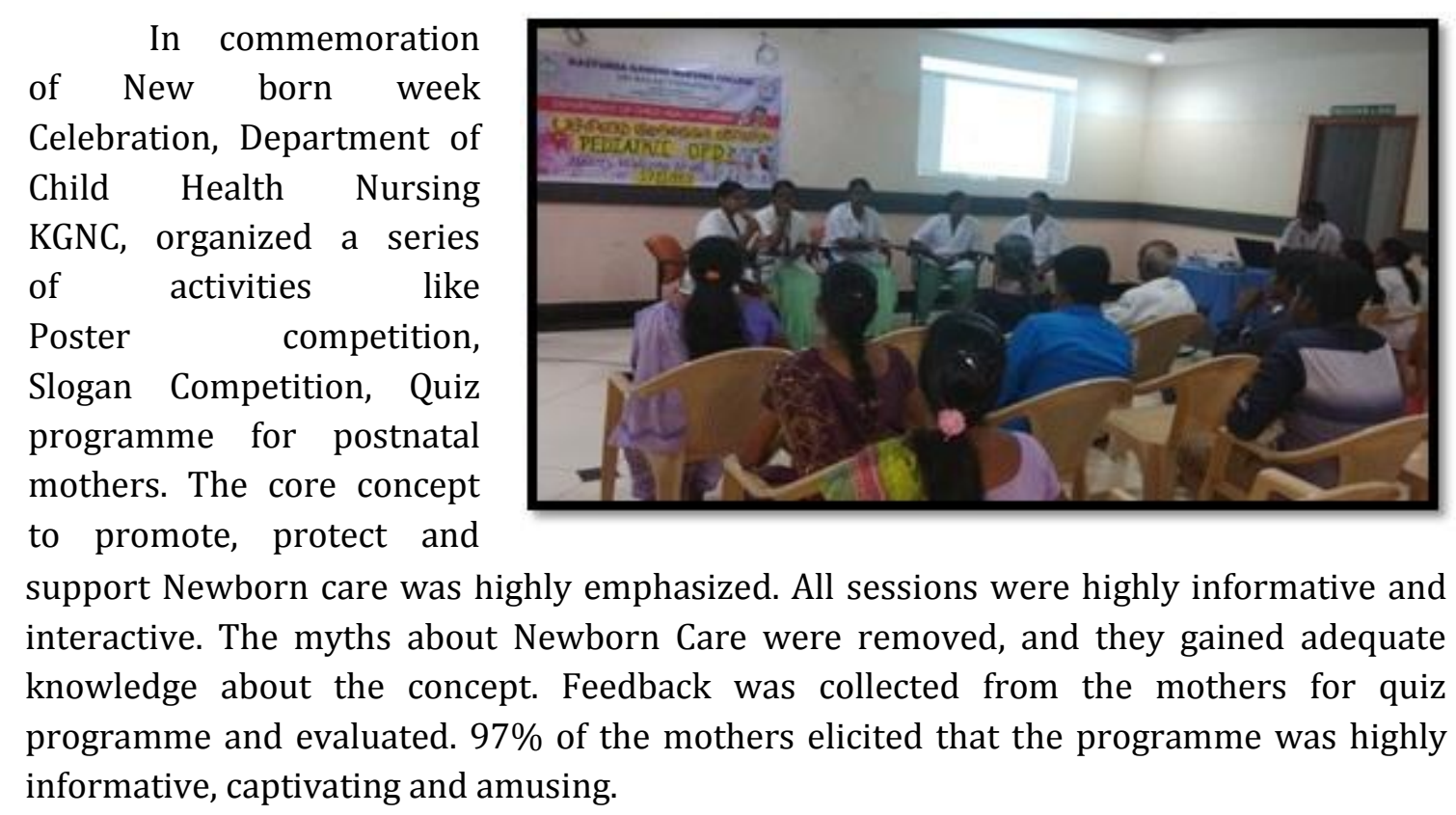

